\title{
Immunotherapy of Lung Cancer: An Update
}

\author{
Dominik Rüttinger ${ }^{a} \quad$ Hauke Winter ${ }^{a} \quad$ Natasja K. van den Engel ${ }^{a} \quad$ Rudolf A. Hatz $^{a}$ \\ Marcus Schlemmer ${ }^{b} \quad$ Heike Pohla ${ }^{c, e} \quad$ Stefanie Grützner ${ }^{d} \quad$ Dolores J. Schendele \\ Bernard A. Fox ${ }^{f} \quad$ Karl-Walter Jauch ${ }^{a}$ \\ a Chirurgische Klinik und Poliklinik, \\ b Medizinische Klinik III, \\ c Labor für Tumorimmunologie, \\ ${ }^{d}$ Klinik für Anästhesiologie, Abteilung für Transfusionsmedizin und Hämostaseologie, Klinikum Grosshadern, \\ Ludwig-Maximilians-Universität München, \\ e GSF - Institut für Molekulare Immunologie, München, Germany \\ ${ }^{f}$ Robert W. Franz Cancer Research Center, Earle A. Chiles Research Institute, Providence Portland Medical Center, Portland, OR, USA
}

Key Words

Lung cancer · Immunotherapy · Vaccines

\section{Summary}

In Germany lung cancer is the leading cause of cancerassociated death in men. Surgery, chemotherapy and radiation may enhance survival of patients suffering from lung cancer but the enhancement is typically transient and mostly absent with advanced disease; eventually more than $90 \%$ of lung cancer patients will die of disease. New approaches to the treatment of lung cancer are urgently needed. Immunotherapy may represent one new approach with low toxicity and high specificity but implementation has been a challenge because of the poor antigenic characterization of these tumors and their ability to escape immune responses. Several different immunotherapeutic treatment strategies have been developed. This review examines the current state of development and recent advances with respect to non-specific immune stimulation, cellular immunotherapy (specific and non-specific), therapeutic cancer vaccines and gene therapy for lung cancer. The focus is primarily placed on immunotherapeutic cancer treatments that are already in clinical trial or well progressed in preclinical studies. Although there seems to be a promising future for immunotherapy in lung cancer, presently there is not standard immunotherapy available for clinical routine.

\author{
Schlüsselwörter \\ Lungenkarzinom · Immuntherapie · Vakzine
}

\section{Zusammenfassung}

Das Bronchialkarzinom führt in Deutschland die Statistik der Krebs-assoziierten Todesfälle bei Männern an, und nimmt bei Frauen den dritten Rang ein. Mehr als $90 \%$ der Patienten mit der Diagnose Bronchialkarzinom versterben trotz der derzeit existierenden Therapien (Operation, Radio- und Chemotherapie). Immuntherapeutische Behandlungsansätze könnten die Anforderungen an eine dringend benötigte, neuartige Therapieform erfüllen: selektive Wirksamkeit gegen Tumorzellen bei gleichzeitig geringen Nebenwirkungen. Bislang litt die Entwicklung immuntherapeutischer Behandlungsstrategien vor allem unter dem begrenzten Wissen über relevante Tumorantigene und Bronchialkarzinom-spezifische Mechanismen, dem Immunsystem des Körpers zu entkommen. Heute zeichnet sich allerdings ab, dass immuntherapeutische Behandlungskonzepte ihren Platz im Rahmen multimodaler Behandlungsansätze im Sinne einer adjuvanten Therapie finden werden. Bis zur klinischen Prüfung wurden bis heute vorwiegend unspezifische Immunmodulatoren, die spezifische und unspezifische, zelluläre Immuntherapie, die therapeutische Vakzinierung und gentherapeutische Behandlungsstrategien in ihrer Entwicklung voran getrieben. Im Folgenden soll eine Übersicht gegeben werden, die für die Therapie des Lungenkarzinoms relevante immuntherapeutische Behandlungsansätze mit Ausnahme der Antikörper-basierten Konzepte beleuchtet und ein besonderes Augenmerk auf neuere Entwicklungen mit bereits abgeschlossenen klinischen Studien legt. Trotz vielversprechender Ansätze gibt es derzeit jedoch keine Standard-Immunotherapie für die klinische Routine.

\begin{tabular}{ll}
\hline KARGER & @ 2006 S. Karger GmbH, Freiburg \\
$\begin{array}{l}\text { Fax +49 761 4520714 } \\
\begin{array}{l}\text { E-mail Information@Karger.de } \\
\text { www.karger.com }\end{array}\end{array}$ & $\begin{array}{l}\text { Accessible online at: } \\
\text { www.karger.com/onk }\end{array}$ \\
&
\end{tabular}

Dr. med. Dominik Rüttinger

Chirurgische Klinik und Poliklinik - Klinikum Großhadern

Ludwig-Maximilians-Universität München

Marchioninistr. 15, 81377 München, Germany

Tel. +49 89 7095-0, Fax -8893

E-mail dominik.ruettinger@med.uni-muenchen.de 


\section{Introduction}

Lung cancer is the leading cause for cancerous death in men in Germany and only $12 \%$ of all patients will ever be cured of this devastating disease. Clearly, there is still an unmet medical need for new adjuvant therapies that demonstrate efficacy in lung cancer with less associated toxicity than chemotherapy. The unfortunate reality is, however, that the field of lung cancer immunotherapy, which may provide a valid alternative for cytotoxic agents, lags behind similar efforts with other kinds of tumors, primarily melanoma, prostate and breast cancer. The main reasons why lung cancer remains difficult to treat by immunotherapeutic approaches also illustrate the difficulties of immunotherapy to become part of the standard treatment modalities for lung cancer:

- In contrast to other tumors such as melanoma, in lung cancer the relevant immunologically dominant antigens remain unknown.

- Many tumors are able to avoid attacks by immunocompetent cells by active and/or passive escape mechanisms, e.g. by downregulating major histocompatibility complexes (MHC) and/or antigens or by the induction of regulatory $\mathrm{T}$ cells that can suppress a destructive antitumor immune response, and thereby become poor targets for cytotoxic T lymphocytes (CTL) or by creating a tumor microenvironment that is very unfavorable to immunocompetent cells by secreting immunoinhibitory factors such as transforming growth factor- $\beta$ or interleukin- 10 .

These general problems provide the theoretical basis for most basic researchers and clinical investigators seeking to develop immunotherapeutic strategies for the treatment of non-small cell lung cancer (NSCLC) and small cell lung cancer (SCLC). Non-specific immune stimulation can be induced by a highly heterogenous group of molecules ranging from intact microbes and bacterial derivatives to cytokines. Most of these agents aim at the induction of both cellular and humoral immune responses by inducing a strong inflammatory response and thus indirectly activating antigen presenting cells (APC) such as dendritic cells. More focus has been placed on specific and non-specific immunotherapy (active and passive) of lung cancer. Therapeutic vaccination using autologous or allogeneic tumor cells (or their defined proteins or peptides) is an example for active-specific immunotherapy that has the potential to be tumor specific as well as to have a systemic impact with relatively few side effects. The most common gene therapy approaches currently applied in the treatment of lung cancer consist of direct genetic modification of tumor cells to replace defective genes ('gene replacement' therapy) or to insert immune stimulating genes with the aim to induce stronger tumor-specific immune responses ('immunogene' therapy). The specific focus of this review is on immunotherapeutic strategies for the treatment of lung cancer that have been taken into the clinic and tested in clinical trials with emphasis on therapeutic vaccination strategies.

\section{Non-Specific Immune Stimulation}

Agents that enhance the immune response of the host against cancer, infectious disease, or immunologic disorders are referred to as 'immunomodulators'. When used for the treatment of cancer, immunomodulators are thought to function as a 'danger signal' to the immune system by inducing changes in APC, in particular dendritic cells, and thereby augmenting both cellular and humoral immunity. Although multiple clinical trials evaluating non-specific immune stimulation for the treatment of lung cancer have been reported (table 1), the success of immunomodulators in cancer immunotherapy has been very limited. For levamisole and thymosin, negative results were reported when used as adjuvant treatment for chemotherapy of lung cancer. While the systemic application of cytokines such as IFN- $\alpha$ and GM-CSF in lung cancer patients also failed to result in significant clinical responses, GMCSF remains within the focus of ongoing research with the use of gene-modified autologous tumor cell vaccines $\left(\mathrm{GVAX}^{\circledR}\right.$, Cell Genesys, Inc., South San Francisco, CA, USA) as an active-specific immunotherapy for NSCLC. Although the enthusiasm for many of the immunomodulators has decreased, there has been a resurgence in approaches targeting co-stimulatory molecules such as CTLA-4, B7 family members, CD40(L) and others. However, to our knowledge, only very little information is available on clinical trials using this approach in patients diagnosed with lung cancer [1].

\section{Cellular Immunotherapy (Specific and Non-Specific)}

The objective of non-specific cellular immunotherapy is to enhance the antitumor effector mechanisms that are not dependent on a specific tumor antigen. Lymphokine-activated killer cells (LAK) are peripheral blood mononuclear cells that have been expanded ex vivo with interleukin-2 (IL-2). In clinical trials, LAK cell therapy was most successful in renal cell carcinoma and melanoma, although further studies indicated that LAK cells did not significantly improve the therapeutic efficacy of IL-2 alone [9]. No clinical benefit was detected after adoptive transfer of lymph node-lymphokine-activated killer cells (LN-LAK) combined with recombinant interleukin 2 (rIL-2) for adjuvant therapy of 19 patients with stage I NSCLC [10]. Kimura et al. did, however, find improved survival in patients with stage II and IIIA lung cancer after treatment with LAK cells and IL-2 in combination with chemotherapy and/or radiotherapy [11, 12].

The use of monokine-activated killer cells (MAK) in clinical trials for lung cancer has been described as a safe procedure [13], however, no detailed information is available as far as clinical outcome is concerned.

Adoptive immunotherapy (AI) by specific cellular transfer can be divided into at least two categories: tumor-infiltrating lymphocytes (TIL) and antigen-specific or tumor-specific cy- 
Table 1. Clinical trials using non-specific immunomodulators in lung cancer

\begin{tabular}{lllcc}
\hline Phase & Indication & Immunomodulator & Patients, $\mathrm{n}$ & Reference \\
\hline I/II & NSCLC/SCLC & BCG & 55 & {$[2]$} \\
I/II & NSCLC/SCLC & C. parvum & 400 & {$[3]$} \\
II & NSCLC & M. vaccae & 20 & {$[4]$} \\
I/II & NSCLC/SCLC & Levamisole & 99 & {$[5]$} \\
I/II & SCLC & Thymosin & 18 & {$[6]$} \\
I/II & NSCLC & IFN- $\alpha$ & 55 & {$[7]$} \\
I & SCLC & GM-CSF & 13 & {$[8]$} \\
\hline
\end{tabular}

Table 2. Therapeutic vaccination in NSCLC published clinical trials

\begin{tabular}{lllll}
\hline Phase & Stage & Vaccine & Patients, $\mathrm{n}$ & Reference \\
\hline II & III/IV & Ctx \pm M. vaccae & 29 & {$[4]$} \\
I & IV & GVAX $^{\circledR}$ & 33 & {$[22]$} \\
I/II & IB-IV & GVAX $^{\circledR}$ & 43 & {$[23]$} \\
I & IIIB/IV & MUC1 & 17 & {$[25]$} \\
I & I/II & MAGE-3 & 17 & {$[27]$} \\
\hline
\end{tabular}

tolytic T lymphocytes (CTL). It is generally recognized that the major effector cell responsible for antitumor immunity is the $\mathrm{CD}^{+} \mathrm{T}$ cell [14]. However, aberrant MHC class I expression is a fundamental obstacle for any cell-based cancer immunotherapy, and NSCLC is no exception [15]. Despite these problems, Kradin et al. [16] and Melioli et al. [17] were able to isolate TILs from resected tumors of patients with NSCLC and reinfused the TILs in combination with subcutaneous application of IL-2. Further studies evaluating the therapeutic efficacy of TIL reinfusion in patients with NSCLC have been able to confirm the moderate clinical effectiveness found in these trials [18]. Other approaches aimed at the isolation of tumor-specific CTLs from the peripheral blood of lung cancer patients that had been vaccinated with their autologous tumor cells [19]. Cancer immunotherapy using the adoptive transfer of TILs or CTLs has, however, seen limited application due to poor response rates and the labor-intensive preparation of the infusion product. Dudley et al. [20] combined the adoptive transfer of both $\mathrm{CD}^{+}$and $\mathrm{CD}^{+}$TILs in patients with metastatic melanoma with a non-myeloablative chemotherapy regimen and observed impressive clinical response rates. A recent update has 16 of 32 patients experiencing an objective clinical response. Currently, clinical trials are being initiated that transfer parts of this strategy to the treatment of other solid tumors.

\section{Therapeutic Vaccination}

In contrast to the prophylactic vaccination against infectious diseases, for cancer patients the only relevant vaccination strategy must be therapeutic. Generally speaking, cancer vaccines incorporate a source of tumor antigens combined with some type of 'adjuvant' to make these tumor antigens visible to the immune system. Sources of tumor-associated antigens include whole autologous or allogeneic tumor cells, defined proteins, or specific peptide epitopes. Most likely due to the heterogeneous histology of lung cancers, the relevant immunologically dominant antigens remain unknown. Therefore, the use of autologous tumor cells might be especially suitable for vaccination strategies in lung cancer, because no prior knowledge of specific tumor antigens is necessary and the induced immunity may not be confined to a single, specific antigen that could be downregulated by the tumor. The genetic modification of autologous tumor cells to secrete immunomodulatory cytokines has been shown to induce antitumor immunity in a number of preclinical models. Of these cytokines GM-CSF has demonstrated the greatest induction of antitumor immunity [21]. Two early phase clinical trials using GM-CSF-secreting, autologous tumor cells (GVAX) in patients with NSCLC have revealed encouraging preliminary results $[22,23]$. In the second trial 83 patients (20 stage I/II, Cohort A; 63 stage III/IV, Cohort B) underwent tumor harvest and vaccine cell processing. Vaccine manufacturing was successful in $80 \%$ of patients. $90 \%$ of patients developed vaccine site reactions. 3 advanced stage patients achieved durable, complete tumor responses lasting 6 and 18 months, and ongoing, respectively. In addition, there was one minor response ( $30 \%$ decrease in a lung nodule), 2 patients with mixed tumor responses, and 7 patients with stable disease (median duration 7.7 months). 2 of the 3 complete responders had failed prior chemotherapy for advanced disease. Currently, further clinical studies are underway investigating autologous GVAX vaccines with and without immunomodulatory doses of cyclophosphamide in all types of NSCLC.

The combination of immunotherapy and chemotherapy has been shown to augment the immune response in both preclinical and human trials [24]. Recent preclinical studies suggest 
Table 3. Therapeutic vaccination in NSCLC - currently active clinical trials as published in the NCI's PDQ, database of cancer clinical trials

\begin{tabular}{|c|c|c|c|}
\hline Phase & Stage & Vaccine & Site \\
\hline $\mathrm{I} / \mathrm{II}$ & n.d. & allogeneic tumor cells expressing $\alpha-1,3$-galactosyltransferase & Bethesda, MD \\
\hline Pilot & unresectable III & $\begin{array}{l}\text { vaccinia-CEA-TRICOM, fowlpox-CEA-TRICOM, recomb. } \\
\text { fowlpox GM-CSF + chemotherapy/radiotherapy }\end{array}$ & Bethesda, MD \\
\hline II & IV & $\begin{array}{l}\text { vaccinia-CEA-TRICOM, fowlpox-CEA-TRICOM, recomb. } \\
\text { fowlpox GM-CSF } \pm \text { chemotherapy }\end{array}$ & Washington, DC \\
\hline II & I-III & autologous DC + allog. tumor cells & Lexington, KY \\
\hline I & IB-IIIA & autologous DC + autol. tumor cells & Los Angeles, CA \\
\hline II & IIIB/IV BAC & $\mathrm{GVAX}^{\circledR}$ & $\begin{array}{l}\text { Sacramento, CA } \\
\text { Kansas City, KA } \\
\text { New Orleans, LA } \\
\text { Arlington, TX }\end{array}$ \\
\hline II & III & autologous $\mathrm{DC}+$ mutant $\mathrm{p} 53$ peptide & Bethesda, MD \\
\hline II & n.d. & $\begin{array}{l}\text { autologous tumor cells treated with interferon } \alpha \text { or interferon } \\
\gamma+\text { chemotherapy }+ \text { GM-CSF }\end{array}$ & Los Angeles, CA \\
\hline
\end{tabular}

n.d.: Not determined. an even higher therapeutic efficacy of cancer vaccines if the system had been made lymphopenic and reconstituted with autologous peripheral blood mononuclear cells (PBMC) [24]. Based on these results, a clinical pilot study in patients with NSCLC stages IIb/IIIa is being initiated in our clinic in 2005 (Klinikum Grosshadern, Ludwig Maximilians University Munich, Germany). These patients will receive immunomodulatory doses of cyclophosphamide and fludarabine and a reinfusion of autologous PBMCs prior to therapeutic vaccination with irradiated autologous tumor cells in combination with the continuous infusion of GM-CSF at the vaccination site.

Vaccination strategies in NSCLC using peptides are rare due to the limited information that is currently available on specific tumor antigens in this disease. The carcinoma-associated mucin, MUC1, which is expressed on the surface of many adenocarcinomas but not on normal epithelial cells has been targeted in a phase I trial of patients with NSCLC using the vaccine BLP25 [25] (table 2). A multicenter phase IIB study investigating the same vaccine in NSCLC patients with stages IIIB and IV has recently been finished with promising results for safety and clinical effectiveness. In this trial, patients were stratified by treatment response and stage (IIIB locoregional or IIIB with malignant pleural effusion/IV) and randomized 1:1 to either best supportive care (BSC) or BSC with BLP-25. 171 patients were randomized. $45 \%$ had stable disease, $51 \%$ showed a partial response and $4 \%$ experienced a complete response. Overall a benefit for patients receiving BSC plus vaccine associated with low toxicity and longer maintenance of quality of life was observed. A phase III trial further investigating BLP-25 is currently being initiated. Another peptide vaccination strategy aims at the peptide MAGE-3, which was originally identified as a melanoma-associated antigen and is expressed in about $30 \%$ of lung cancers [26]. A multinational phase II trial investigating the therapeutic efficacy of the MAGE-3 peptide vaccine in patients with resected MAGE- $3^{+}$ stage IB/II NSCLC is currently underway. First results reporting the successful induction of humoral and cellular immune responses in patients with NSCLC following vaccination with MAGE-3 with and without adjuvant have been published in 2004 [27].

Table 3 summarizes currently active vaccine trials for NSCLC as published in the NCI's PDQ ${ }^{\circledR}$ database of cancer clinical trials (http://www.cancer.gov/search/clinicaltrials).

In SCLC, an anti-idiotype vaccine targeting the ganglioside GD3 (BEC2) (mitumomab) has been evaluated [28]. A pilot study of BEC2 plus BCG was performed in 15 patients with both limited and extensive SCLC following demonstration of a substantial response to chemotherapy. Patients received a series of 5 intradermal vaccinations. All patients developed anti-BCE2 antibodies with 5 patients developing anti-GD3 antibodies. The median overall survival was 21 months with a 4-year survival rate of $40 \%$. The European Organization for Research and Treatment of Cancer (EORTC) is currently assessing data from a phase III trial using BEC2 in combination with induction chemoradiotherapy in limited stage SCLC.

Other therapeutic vaccination strategies for patients with NSCLC and SCLC are in the early phase of clinical development:

- G17DT, which links diphteria toxin to a gastrin-17 receptor binding epitope [29] (so far, published results are limited to treatment of gastrointestinal malignancies but SCLC reveals high expression of gastrin),

- mp53DC, which consists of dendritic cells that had been pulsed with mutant p53 [30],

- fucosyl GM1-KLH, another mucin peptide vaccine [31, 32],

- polysialic acid-KLH, a vaccine consisting of long chain polysialic acid, which is, in adults, largely restricted to SCLC, and keyhole limpet hemocyanin (KLH) as adjuvant [33],

- fowlpox-CEA/vaccinia-CEA, which uses viral vectors that express the mucin CEA [34]. 


\section{Lung Cancer Gene Therapy}

Even though gene therapy is not the primary focus of this review, a short overview should be given since both hereditary and environmental factors are causative of genetic abnormalities in lung cancer.

\section{'Gene Replacement' Therapy}

Preclinical and clinical studies in this area of gene therapy research aim mostly at the most commonly mutated gene in lung cancer: p53 (mutations have been identified in $50-70 \%$ of lung tumors). With its involvement in cell cycle regulation, DNA repair and apoptosis, p53 is essential for controlling the integrity of the genome. At least 3 phase I clinical trials have been conducted to investigate biosafety and therapeutic efficacy of p53 substitution [35]. Each study was able to demonstrate the safety of this approach and stabilization of disease was achieved [36]. However, to date, no gene transfer system (e.g. viral vectors) is efficient enough to meet the theoretical need to genetically modify every cancer cell to achieve an optimal antitumor effect. In addition, immunity against the viral vector may compromise the efficiency of this approach. Current preclinical studies, therefore, investigate novel gene transfer vehicles which are less immunogenic.

Another frequent therapeutic target in lung cancer gene replacement therapy strategies is the ras oncogene. Ras mutations are found in approximately $20 \%$ of adenocarcinomas.

\section{'Suicide' Gene Therapy}

The in vivo delivery of a 'suicide' gene to tumor cells is supposed to result in their selective sensitization to a systemically administered drug. The most prominent example is the herpes simplex thymidine kinase (HSV-tk) gene that encodes for an enzyme that converts the normally nontoxic gancyclovir into a toxic compound. While there are no reports on clinical application of this approach in patients with lung cancer, there is clinical data utilizing an adenoviral vector to deliver the HSVtk gene to patients with mesothelioma via intra-pleural administration [37].

\section{'Immuno' Gene Therapy}

As described above with therapeutic vaccines, immuno gene therapy aims at enhancing the immunogenicity of lung tumors and, ultimatively, at inducing a systemic antitumor immune re- sponse. Most research efforts in NSCLC/SCLC concentrate on the ex vivo genetic modification of autologous tumor cells, tumor infiltrating lymphocytes or dendritic cells to secrete immunostimulatory cytokines such as IL-2, IL-7 and most of all GM-CSF [21]. The resulting products have been used for adoptive cell transfer, therapeutic vaccination, intra-tumoral application and others. Another promising approach in lung cancer may be vaccination using gene-modified viral vectors. Promising early results have been reported for a highly attenuated vaccinia virus vector (modified vaccinia Ankara, MVA) encoded to express the epithelial cancer antigen MUC1 with coexpression of IL-2 [38].

One of the most promising preclinical developments of immunogene therapy targeting the tumor neovascularization involves delivery of a mutant Raf gene to angiogenic blood vessels using integrin-targeted liposomes [39].

Another immuno gene therapy approach is based on the infusion of an oligonucleotide sequence that is complimentary to a specific mRNA (antisense), selectively downregulating expression of that protein. Using this strategy, Villalona-Calero et al. [40] applied the antisense inhibitor of protein kinase C- $\alpha$ in combination with chemotherapy in patients with advanced NSCLC and found an overall response rate of $36 \%$ in their phase II study.

\section{Conclusion}

The limited information available concerning the antigenic repertoire of NSCLC and SCLC and the ability to circumvent the immune response make lung cancer a particularly difficult target for immunotherapeutic treatment strategies. However, over the past decades significant advances have been made and different approaches have been taken from bench to clinic. It remains hopeful that immunotherapy may become part of today's established therapies for patients diagnosed with lung cancer. As a minimally toxic and targeted therapy, therapeutic vaccination might be of particular interest to those treating this terrible disease.

\section{Acknowledgement}

D.R. was a Chiles Foundation Visiting Fellow. The authors form the Munich NSCLC vaccine study group.

\section{References}

1 Raez LE, Cassileth PA, Schlesselman JJ, Padmanabhan S, Fisher EZ, Baldie PA, Sridhar K, Podack ER: Induction of CD8 T-cell-Ifn-gamma response and positive clinical outcome after immunization with gene-modified allogeneic tumor cells in advanced non-small-cell lung carcinoma. Cancer Gene Ther 2003;10:850-858.
2 Millar JW, Roscoe P, Pearce SJ, Ludgate S, Horne NW: Five-year results of a controlled study of BCG immunotherapy after surgical resection in bronchogenic carcinoma. Thorax 1982;37:57-60.

3 Bast RC, Zbar B, Borsos T, Rapp HJ: BCG and cancer. N Engl J Med 1974;290:1458-1469.
4 O'Brien ME, Saini A, Smith IE, Webb A, Gregory K, Mendes R, Ryan C, Priest K, Bromelov KV, Palmer RD, Tuckwell N, Kennard DA, Souberbielle BE: A randomized phase II study of SRL172 (Mycobacterium vaccae) combined with chemotherapy in patients with advanced inoperable nonsmall-cell lung cancer and mesothelioma. Br J Cancer 2000;83:853-857. 
5 Anthony HM, Mearns AJ, Mason MK, Scott DG, Moghissi K, Deverall PB, Rozycki ZJ, Watson DA: Levamisole and surgery in bronchial carcinoma patients: increase in deaths from cardiorespiratory failure. Thorax 1979;34:4-12.

6 Cohen MH, Chretien PB, Ihde DC, Fossieck BE, Makuch R, Bunn PA, Johnston AV, Shackney SE, Matthews MJ, Lipson SD, Kenady DE, Minna JD: Thymosine fraction $\mathrm{V}$ and intensive combination chemotherapy. JAMA 1979;241:1813-1815.

7 Agarwala SS: Interferon-alpha and -beta: clinical applications; in Rosenberg SA (ed): Principles and Practice of the Biologic Therapy of Cancer. Philadelphia, PA, Lippincott Williams \& Wilkins, 2000, pp 275-285.

8 Aman MJ, Stockdreher K, Thews A, Kienast A, Aulitzky WE, Farber L, Haus U, Koci B, Huber C, Peschel C: Regulation of immunomodulatory functions by granulocyte-macrophage colony-stimulating factor in vivo. Ann Hematol 1996;73:231-238.

9 Bermers AJA, Parmiani G: Immunology and immunotherapy of human cancer: present concepts and clinical developments. Crit Rev Oncol Hematol 2000;34:1-25.

10 Yano T, Sugio K, Yamazaki K, Kase S, Yamaguchi M, Ondo K, Yoshino I, Sugimachi K: Postoperative adjuvant adoptive immunotherapy with lymph node-LAK cells and IL-2 for pathologic stage I non-small cell lung cancer. Lung Cancer 1999;26: 143-148.

11 Kimura H, Yamaguchi Y: A phase III randomized study of interleukin-2 lymphokine-activated killer cell immunotherapy combined with chemotherapy or radiotherapy after curative or noncurative resection of primary lung carcinoma. Cancer 1997;80: 42-49.

12 Kimura Y, Yamaguchi Y: Adjuvant chemo-immunotherapy after curative resection of Stage II and IIIA primary lung cancer. Lung Cancer 1996; 14:301-314.

13 Faradji A, Bohbot A, Schmitt-Goguel M, Roeslin N, Dumont S, Wiesel ML, Lallot C, Eber M, Bartholeyns J, Poindron P: Phase I trial of intravenous infusion of ex-vivo-activated autologous blood-derived macrophages in patients with non-small-cel lung cancer: toxicity and immunomodulatory effects. Cancer Immunol 1991;33:319-326.

14 Carbone FR, Bevan MJ: Class I-restricted processing and presentation of exogenous cell-associated antigen in vivo. J Exp Med 1990;171:377-387.

15 Korkolopoulou P, Kaklamanis L, Pezzella F, Harris AL, Gatter KC: Loss of antigen-presenting molecules (MHC class I and TAP-I) in lung cancer. Br J Cancer 1996;73:148-153.

16 Kradin RL, Boyle LA, Preffer FI, Callahan RJ, Barlai-Kovach M, Strauss HW, Dubinett S, Kurnick JT: Tumor-derived interleukin-2-dependent lymphocytes in adoptive immunotherapy of lung cancer. Cancer Immunol Immunother 1987;24:76-85.

17 Melioli G, Ratto GB, Ponte M, Guastella M, Semino C, Fantino G, Tassara E, Pasquetti W, Mereu C, Merlo F, Reggiardo G, Morasso G, Santi L, Moretta L: Treatment of stage IIIb NSCLC with surgery followed by infusion of tumor infiltrating lymphocytes and recombinant interleukin-2: a pilot study. J Immunother Emphasis Tumor Immunol 1996;19:224 230.
18 Ratto GB, Zino P, Mirabelli S, Minuti P, Aquilinia R, Fantino G, Spessa E, Ponte M, Bruzzi P, Melioli $\mathrm{G}$ : A randomized trial of adoptive immunotherapy with tumor-infiltrating lymphocytes and interleukin-2 versus standard therapy in the postoperative treatment of resected non small cell lung carcinoma. Cancer 1996;78:244-251.

19 Chan B, Lee W, Hu CXL, Ng P, Li KW, Lo G, Ho G, Yeung DW, Woo D: Adoptive cellular immunotherapy for non-small cell lung cancer: a pilot study. Cytotherapy 2003;5:46-54.

20 Dudley ME, Wunderlich JR, Robbins PF, Yang JC, Hwu P, Schwartzentruber DJ, Topalian SL, Sherry R, Restifo NP, Hubicki AM, Robinson MR, Raffeld M, Duray P, Seipp CA, Rogers-Freezer L, Morto KE, Mavroukakis SA, White DE, Rosenberg SA: Cancer regression and autoimmunity in patients after clonal repopulation with antitumor lymphocytes. Science 2002;298:850-854.

21 Dranoff G, Jaffee E, Lazenbay A: Vaccination with irradiated tumor cells engineered to secrete murine granulocyte-macrophage colony-stimulating factor stimulates potent, specific, and long-lasting antitumor immunity. Proc Natl Acad Sci USA 1993;90: 3539-3543.

22 Salgia R, Lynch T, Skarin A, Lucca J, Lynch C, Jung K, Hodi FS, Jaklitsch M, Mentzer S, Swanson S, Lukanich J, Bueno R, Wain J, Mathisen D, Wright C, Fidias P, Donahue D, Clift S, Hardy S, Neuberg D, Mulligan R, Webb I, Sugarbaker D, Mihm M, Dranoff G: Vaccination with irradiated autologous tumor cells engineered to secrete granulocytemacrophage colony stimulating factor augments anti-tumor immunity in patients with metastatic non-small cell lung carcinoma. J Clin Oncol 2003; 21:624-630.

23 Nemunaitis J, Sterman D, Jablons D, Smith JW, Fox B, Maples P, Hamilton S, Borellini S, Lin A, Morali S, Hege K: Granulocyte-macrophage colony-stimulating factor gene-modified autologous tumor vaccines in non-small-cell lung cancer. J Natl Cancer Inst 2004;96:326-331.

24 Ma J, Poehlein CH, Jensen S, Lacelle MG, Moudgil TM, Rüttinger D, Haley D, Goldstein M, Smith III JW, Curti B, Ross H, Walker E, Hu HM, Urba WJ, Fox BA: Manipulating the host response to autologous tumor vaccines. Dev Biol (Basel) 2004;116: 93-107.

25 Palmer M, Parker J, Modi S, Butts C, Smylie M, Meikle A, Kehoe M, MacLean G, Longenecker M: Phase I study of the BLP25 (MUC1 Peptide) liposomale vaccine for active specific immunotherapy in stage IIIB/IV non-small-cell lung cancer. Clin Lung Cancer 2001;3:49-57.

26 Gotoh K, Yatabe Y, Sugiura T, Takagi K, Ogawa M, Takahashi T, Mitsudomi T: Frequency of MAGE-3 gene expression in HLA-A2 positive patients with non-small cell lung cancer. Lung Cancer 1998;20:117-125.

27 Atanackovic D, Altorki NK, Stockert E, Williamson B, Jungbluth AA, Ritter E, Santiago D, Ferrara CA, Matsuo M, Selvakumar A, Dupont B, Chen YT, Hoffmann EW, Ritter G, Old LJ, Gnjatic $\mathrm{S}$ : Vaccine-induced $\mathrm{CD} 4+\mathrm{T}$ cell responses to MAGE-3 protein in lung cancer patients. J Immunol 2004;172:3289-3296.

28 Grant SC, Kris MG, Houghton AN, Chapman PB: Long survival of patients with small cell lung cancer after adjuvant treatment with the anti-idiotypic antibody BEC2 plus bacillus calmette-guerin. Clin Cancer Res 1999;5:1319-1323.
29 Smith A, Justin T, Michaeli D, Watson SA: Phase I/II study of G17-DT, an anti-gastrin immunogen, in advanced colorectal cancer. Clin Cancer Res 2000;6:4719-4724.

30 Nikitina E, Clark J, Van Beynen J, Chada S, Virmani AK, Carbone DP, Gabrilovich DI: Dendritic cells transduced with full-length wild-type p53 generate anti-tumor cytotoxic T lymphocytes from peripheral blood of cancer patients. Clin Cancer Res 2001;1:2-4.

31 Dickler M, Ragupathi G, Liu N, Musselli C, Martino DJ, Miller VA, Kris MG, Brezicka FT, Livingston PO, Grant SC: Immunogenicity of a fucosyl-GM1-keyhole limpet hemocyanin conjugate vaccine in patients with small cell lung cancer. Clin Cancer Res 1999;5:2773-2779.

32 Krug LM, Ragupathi G, Hood C, Kris MG, Miller VA, Allen JR, Keding SJ, Danishefsky SJ, Gomez J, Tyson L, Pizzo B, Baez V, Livingston PO: Vaccination of patients with small-cell lung cancer with synthetic fucosyl GM-1 conjugated to keyhole limpet hemocyanin. Clin Cancer Res 2004;10: 6094-6100.

33 Krug LM, Ragupathi G, Ng KK, Hood C, Jennings HJ, Guo Z, Kris MG, Miller V, Pizzo B, Tyson L, Baez V, Livingston PO: Vaccination of small cell lung cancer patients with polysialic acid or N-propionylated polysialic acid conjugated to keyhole limpet hemocyanin. Clin Cancer Res 2004;10: 916-923.

34 Marshall JL, Arlen PM, Rizvi N: A phase I study of sequential vaccinations with fowlpox-CEA (6D) Tricom (B7/ICAM/LFA3) alone, and in combination with vaccinia-CEA (6D)-Tricom and GM-CSF in patients with CEA expressing carcinomas. Proc Am Soc Clin Oncol 2002;21:7a.

35 Swisher S, Roth J: Clinical update of Ad-p53 gene therapy for lung cancer. Surg Oncol Clin North Am 2002;11:521-535.

36 Roth JA, Grammer SF: Gene replacement therapy for non-small cell lung cancer: a review. Hematol Oncol Clin N Am 2004;18:215-229.

37 Sterman D, Treat J, Litzky L: Adenovirus-mediated herpes simplex virus thymidine kinase gene delivery in patients with localized malignancy: results of a phase I clinical trial in malignant mesothelioma. Hum Gene Ther 2000;9:1083-1092.

38 Liu M, Acres B, Balloul JM, Bizouarne N, Paul S, Slos P, Squiban P: Gene-based vaccines and immunotherapeutics. PNAS 2004;101:14567-14571.

39 Hood JD, Bednarski M, Frausto R, Guccione S, Reisfeld RA, Xiang R, Cheresh DA: Tumor regression by targeted gene delivery to the neovasculature. Science 2002;296:2404-2407.

40 Villalona-Calero MA, Ritch P, Figueroa JA, Otterson GA, Belt R, Dow E, George S, Leonardo J, McCachren S, Miller GL, Modiano M, Valdivieso M, Geary R, Oliver JW, Holmlund J: A phase I/II study of LY900003, an antisense inhibitor of protein kinase $\mathrm{C}-\alpha$, in combination with cisplatin and gemcitabine in patients with advanced non-small cell lung cancer. Clin Cancer Res 2004;10:60866093.

Rüttinger/Winter/van den Engel/Hatz/ Schlemmer/Pohla/Grützner/Schendel/Fox/ Jauch 